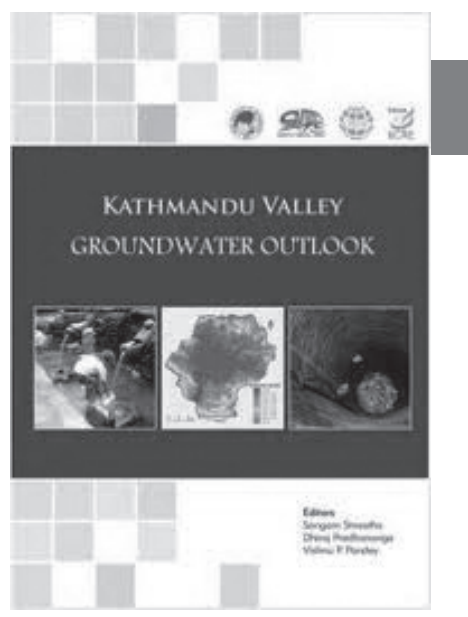

\title{
Kathmandu Valley Groundwater Outlook
}

Edited by Sangam Shrestha, Dhiraj Pradhananga and Vishnu P. Pandey; Kathmandu, Nepal; Publishers:- Asian Institute of Technology (AIT), The Small Earth Nepal (SEN), Center of Research for Environment Energy and Water (CREEW), and International Research Center for River Basin Environment-University of Yamanashi (ICRE-UY), Japan; 146pp., Individual NRs.500 (US\$5.65) and Institutional NRs.1,500 (US\$17)

$\mathbf{T}$ The book is a peer reviewed collection of articles/ research papers written by professionals. It has an attractive formatting, and the articles are well written, reviewed and edited. It is a comprehensive book on the mentioned subject covering almost all the aspects of Kathmandu Valley's groundwater. Due to the very high rate of urbanization and ever escalating population of the Kathmandu Valley, groundwater has increasingly become the main source of water for the Valley. The exploitation of this resource is far greater than the sustainable level, and in future the situation is expected to deteriorate further with risk of land subsidence.

\section{The following one paragraph (excerpted) as introduction} to the book clearly highlights its objective:-

"Groundwater is an important source of water for communities and industries in the Kathmandu Valley. Unfortunately, uncontrolled extraction and use of groundwater and improper management of both solid waste and wastewater from urban centers have increased the vulnerability of groundwater to depletion and degradation. A lack of appropriate documentation as well as insufficient dissemination of results from studies on groundwater carried out by various stakeholders over the decades has also resulted in problems with both baseline data loss and knowledge redundancy. In response to these current circumstances, this book aims to prioritize present issues related to groundwater in the Kathmandu Valley, reclaim available information and baseline data from earlier studies, compile the latest scientific understandings of relevant pressing issues, and organize those issues as well as potential approaches to contending with them within a single volume. As such, this book also provides a scientific foundation to advocate for appropriate policies as well as for the need of subsequent institutional and legal arrangements for sustainable development and management of the Kathmandu Valley's groundwater resources."

The book covers introduction, quantity, quality, use and institution/policies pertaining to groundwater. Following is a section-wise review of the book:

Section I: Introduction:- In this section, there are two articles; (a) Introduction and (b) Comprehensive Review of Groundwater Research in the Kathmandu Valley, Nepal.

A table showing the various research programs/ investigations is presented here. This chapter mentions that important researches were undertaken and due to lack of dissemination/proper documentation, such researches were repeated. It emphasizes the need for compiling and disseminating the latest results through a single window. The second paper of this section has given a comprehensive review of groundwater research covering aspects such as physiography, quantity, quality, development and management. It gives a table showing different research papers published on the subject.

Section II: Groundwater Quantity:- Under this section, three papers are presented, namely:

a) Geology and Hydrogeology of Groundwater Aquifers in the Kathmandu Valley,

b) Groundwater Storage Potential in the Kathmandu Valley's Shallow and deep Aquifers, and

c) Shallow Groundwater Recharge Altitudes.

The paper headings are self explanatory. It mainly focuses on three distinct areas of the Kathmandu Valley the North which is a recharge zone; and, the middle and the south zone. Due to the thick layer of clay, the middle and the southern region contribute very small recharge.

Important figures are given regarding the total storage, annual recharge, specific storage constants, and annual withdrawals etc.

The valley has two distinct aquifers, a) Shallow, and b) Deep. Up to $85 \mathrm{~m}$ depth is considered shallow.

The deep aquifer is about 2,00,000 to 4,00,000 years old. The recharge is limited to this aquifer. The annual withdrawal is 20 times more than the recharge on this aquifer.

The important statistics depict the total storage of the shallow aquifer as 1.5 BCM; whereas that of the deep aquifer as $0.6 \mathrm{BCM}$. The spatial variation is 100 to $6800 \mathrm{~m}^{3} / 400 \mathrm{~m}^{2}$, whereas the maximum storage for the deep aquifer is less than $1000 \mathrm{~m}^{3} / 400 \mathrm{~m}^{2}$. The estimated rate of groundwater use is $21.56 \mathrm{MCM} /$ year (2001 data) that translates to less than 100 years time to deplete the shallow and deep aquifers. 
The second paper has given an estimate of the annual possible recharge as 226.5 $\mathrm{MCM}$ in the shallow aquifer of the Kathmandu valley based on the water table data of the month of July and Specific yield of 0.2. This reviewer feels that the estimate is very high compared to the reality due to the $4.7 \mathrm{~m}$ of available recharge depth assumed, high specific yield of 0.2 in the shallow aquifer and recharge upto $0.5 \mathrm{~m}$ below the average ground level (bagl). The three parameters mentioned do not seem to be realistic. Because, at the end of the monsoon, the ground water table is almost to the ground level (about $5 \mathrm{ft}$ below ground level) in the city area, specific yield of shallow aquifer given in the same book varies between 0.1 to 0.19 , and if the recharge is made upto $0.5 \mathrm{bagl}$, then most of the area will be water logged. Innovative techniques will be required to recharge, say by storing water in ponds/reservoirs and slowly recharging to fill up the ongoing depletion.

The third paper in this section deals with how to determine/ locate the recharge altitude for the shallow aquifer by use of stable isotopes. The conclusion is that the recharge in the shallow aquifer comes from the Valley floor itself and not from the surrounding hills area. Due to its highly technical nature, this paper is not comprehensible for the general readers.

Section III: Groundwater Quality:- There are three papers in this section, namely; a) Overview of Chemical Quantity of Groundwater, b) Microbial Pollution in Groundwater and Surface Water c) Attached Growth System for NH4-N Removal from Groundwater.

The three papers in the section have covered in detail the chemical and microbial pollution of groundwater of Kathmandu Valley. The pollution level is very high with the presence of E-coli, not suitable for drinking purposes. The main reason given is the seepage from polluted rivers and ponds to the ground water aquifer.

The papers mostly compares the quality with WHO standard; whereas Nepal has developed its own standard/ guidelines which are not used.

Section IV: Groundwater Use:- This section contains three papers a) Analysis of Domestic Water Use, b) Groundwater Use-An Analysis of Pre- and PostMelamchi Scenarios, and c) Overview of the Water Market in the Kathmandu Valley.

The system is being designed based on the 135 lpcd water use; however, the actual use rate at present is 41 lped. The total demand in the valley in the wet season is 350 MLD whereas the supply has been only 105 MLD and 75.5 MLD respectively. Sixty Five percent (personal communication with Mr. Suresh Acharya, KUKL spokesperson) of the water supply (in dry season) in the
Valley comes from groundwater. Kathmandu Upatyaka Khanepani Limited (KUKL) is the largest extractor of groundwater. Different papers of the book give different data on water use/ ground water withdrawal rate. Data given on the groundwater withdrawal in valley is $35 \%$ in dry and $11 \%$ in wet season which is lowerside than the reality.

In the paper on water use in Pre- and Post- Melamchi scenario, an interesting figure is presented showing declining groundwater use and increasing surface water supply from 2011 onwards. It seems to be based on old data, because the Melamchi Water Supply Project is not likely be commissioned in the next four years. Due to delays in the commissioning of the Melamchi project and increasing population of Kathmandu, it is difficult to believe that the ground water use will be drastically reduced. In fact, the regulator, Kathmandu Valley Water Supply Management Board (KVWSMB), needs to be more vigilant to restrict haphazard withdrawal of the groundwater in Kathmandu valley.

The paper on overview of water markets discusses the rapidly growing water markets in the Valley i.e. supply of water through tankers etc.

Section V: Institutions and Policies:- This section discusses with briefs the various water related institutions (governmental and non-governmental) with their mandate, and activities. Various water related polices are also described.

Annex: Contains, i) Table showing comprehensive list of Research on Kathmandu valley's groundwater. There is an inventory of various stone spouts in the five municipalities of the Valley stating their present status and brief past history. Furthermore, briefs on the Editors, Authors, etc. are given with photographs.

Dr. David Molden, DG, ICIMOD, has righty pointed that this book is an important contribution to the sustainable development, management and governance of the ground water resource in the Valley. The Editors and the author suggest further research work to be done on the ground water resource of the Kathmandu Valley. This Reviewer feels that much research has already been done in the past, sometimes with duplication; and now is the time for action such as recharging the ground water, and dissemination of the main results to the general public, etc. It is a must read book for policy makers and any enthusiast on water.

The Editors and publishers have done an exemplary job in producing this very useful and practical book. HYDRO Nepal Team Congratulates the Team for their hard work and dedication. 